\title{
Host Range of Verticillium isaacii and Verticillium klebahnii from Artichoke, Spinach, and Lettuce
}

Suraj Gurung and Dylan P. G. Short, Department of Plant Pathology, University of California, Davis, c/o U.S. Agricultural Research Station, Salinas 93905; Xiaoping Hu, State Key Laboratory of Crop Stress Biology for Arid Areas and College of Plant Protection, Northwest A\&F University, Yangling, Shaanxi, China; German V. Sandoya, The Genome Center and Department of Plant Sciences, University of California, Davis; Ryan J. Hayes, United States Department of Agriculture-Agricultural Research Service, Salinas, CA 93905; Steven T. Koike, University of California Cooperative Extension, Salinas 93901; and Krishna V. Subbarao, Department of Plant Pathology, University of California, Davis, c/o U.S. Agricultural Research Station, Salinas

\begin{abstract}
Gurung, S., Short, D. P. G., Hu, X., Sandoya, G. V., Hayes, R. J., Koike, S. T., and Subbarao, K. V. 2015. Host range of Verticillium isaacii and Verticillium klebahnii from artichoke, spinach, and lettuce. Plant Dis. 99:933-938.

Verticillium is a genus that includes major vascular wilt pathogens. Recently, multilocus phylogenetic analyses of the genus identified five new species, including Verticillium isaacii and V. klebahnii, both of which occur in agricultural soils in coastal California and have been isolated from asymptomatic and diseased spinach and lettuce plants. Little data are available regarding their pathogenicity and virulence on a broader range of crops important to the region. Four isolates each of $V$. isaacii and V. klebahnii along with two reference isolates of $V$. dahliae races 1 and 2 were inoculated on eight crops (artichoke, cauliflower, eggplant, lettuce, pepper, tomato, spinach, and strawberry) in a greenhouse experiment. After 8 weeks, plants were assessed for disease severity to determine the relative host ranges of Verticillium isolates. Additionally, 13 lettuce lines resistant to race 1 and

partially resistant to race 2 of $V$. dahliae were screened against $V$. isaacii and $V$. klebahnii to evaluate their responses. Three of four $V$. isaacii and four of four $V$. klebahnii isolates tested were nonpathogenic on all crops tested except those indicated below. One $V$. isaacii isolate caused wilt on artichoke and 'Salinas' lettuce and most isolates of both species caused varying degrees of Verticillium wilt on strawberry. Lettuce lines resistant to $V$. dahliae race 1 and partially resistant to $V$. dahliae race 2 also exhibited resistance to all of the isolates of $V$. isaacii and $V$. klebahnii. Thus, at least some isolates in the populations of $V$. isaacii and $V$. klebahnii have the potential to become significant pathogens of coastal California crops. However, resistance developed against $V$. dahliae also offers resistance to the pathogenic isolates of both species, at least in lettuce.
\end{abstract}

Verticillium spp. are soilborne fungal pathogens that cause vascular wilts in more than 400 plant species. A comprehensive reassessment of the systematics and taxonomy of the genus Verticillium by Inderbitzin et al. (2011) delineated strongly supported species boundaries within the genus Verticillium and described five new species. The phylogenetic tree that Inderbitzin et al. (2011) constructed based on multigene phylogenies included two large clades with five species each. Species in clade Flavexudans produce a yellow pigment in culture and includes Verticillium albo-atrum, V. isaacii, V. klebahnii, V. tricorpus, and V. zaregamsianum; in contrast, species in clade Flavnonexudans produce no pigmentation and include $V$. alfalfae, V. dahliae, V. nonalfalfae, V. nubilum, and the hybrid $V$. longisporum, of which $V$. dahliae is by far the most economically important, followed by $V$. longisporum. The other species from this clade cause Verticillium wilt in a limited number of plant species.

$V$. tricorpus sensu stricto is morphologically cryptic with $V$. isaacii and V. klebahnii (Inderbitzin et al. 2011). V. tricorpus is known to occur only in Japan, The Netherlands, and the United Kingdom. Reports of Verticillium wilt caused by the morphospecies "V. tricorpus" in California and elsewhere in the United States, prior to phylogenetic circumscription, was therefore likely to be caused by either $V$. isaacii or $V$. klebahnii. Previous host range experiments based on a limited number of plant species has suggested the existence of potential differences in host ranges between the three aforementioned Verticillium spp. (Isaac 1953; Vallad et al. 2006).

The number of plant species known to be susceptible to Verticillium wilt has steadily increased as epidemics have appeared on crops

Corresponding author: K. V. Subbarao; E-mail: kvsubbarao@ucdavis.edu

S. Gurung and D. P. G. Short contributed equally to this study.

Accepted for publication 25 January 2015.

http://dx.doi.org/10.1094/PDIS-12-14-1307-RE

(C) 2015 The American Phytopathological Society previously considered immune or not susceptible (Pegg and Brady 2002). In the late 1980 s, Verticillium wilt caused by V. longisporum became severe in commercial cauliflower fields in coastal California (Koike et al. 1994). The Salinas and Pajaro Valleys are home to $>85 \%$ of fresh-market spinach and $60 \%$ of lettuce production in the United States (Anonymous 2011, 2012) and, although lettuce was historically considered to be immune to $V$. dahliae, it was recognized as a host in 1995 (Subbarao et al. 1997). The disease has since expanded its geographical range to become a significant problem for lettuce production (Atallah et al. 2011; Gurung et al. 2014). As of 2013, Verticillium wilt on lettuce had spread to multiple fields in coastal California and caused millions of dollars in yield losses annually (Gurung et al. 2014). Although Verticillium wilt of lettuce caused by $V$. dahliae is currently restricted to coastal California in the United States, Verticillium wilt caused by V. tricorpus was reported from Washington (Powell et al. 2013). The National Center for Biotechnology Information GenBank accessions and the phylogenetic analysis of the sequence data from Powell et al. (2013) clearly place this pathogen within $V$. isaacii. Verticillium wilt of spinach, although known (du Toit et al. 2005; Short et al. 2014, 2015), is not a problem in spinach production because the crop is harvested well before symptom onset, which coincides with bolting and flowering.

The phase-out of the soil fumigant methyl bromide in 2015 is likely to increase the range and incidence of soilborne diseases in coastal California. Thus, it is reasonable to expect that the reservoirs of $V$. dahliae and other fungi present in the soil but currently not known to cause diseases may emerge to have a greater impact on crops in the area. In disease surveys, $V$. isaacii and $V$. klebahnii were frequently recovered from lettuce and artichoke fields in California (Qin et al. 2008). Similarly, Short et al. (2015) frequently recovered $V$. isaacii, $V$. dahliae, and V. klebahnii isolates during surveys of commercial spinach fields from 2010 to 2012. The relative roles of $V$. isaacii and $V$. klebahnii in the Verticillium wilt complex in lettuce production and other crops in coastal California are unknown. Finally, the effectiveness of $V$. dahliae-resistant lettuce accessions and cultivars, which includes race 1 resistance, mediated by the plant resistance gene $\operatorname{Vrl}$ (Hayes et al. 2011b) and several lines identified 
as partially resistant to race 2 (Hayes et al. 2007), has not been tested against Verticillium spp. other than $V$. dahliae.

The objectives of the present study were to (i) determine the host range of multiple isolates of $V$. isaacii and $V$. klebahnii on major crops grown in coastal California relative to the two races of $V$. dahliae and (ii) test several lettuce cultivars that are partially resistant to $V$. dahliae against isolates of $V$. isaacii pathogenic to lettuce and artichoke and isolates of V. klebahnii pathogenic to strawberry.

\section{Materials and Methods}

Pathogenicity assays of $V$. dahliae, $V$. isaacii, and V. klebahnii in the greenhouse. Four isolates each of $V$. isaacii (Cello-A-Tri-P [spinach], PD 341 [lettuce], PD 661 [lettuce], and PD 752 [spinach]) and V. klebahnii (PD 347 [artichoke], PD 407 [lettuce], PD 458 [lettuce], and PD 659 [lettuce]), and two isolates of $V$. dahliae representing race 1 (Ls. 16) and 2 (Ls. 17) were tested on artichoke ('5473/91 black'), cauliflower ('Snowball'), eggplant ('Long Purple'), lettuce 'La Brillante' (resistant to race 1 of $V$. dahliae), lettuce 'Salinas' (susceptible to both $V$. dahliae races), pepper ('California Wonder'), spinach ('Hector'), strawberry ('Albion'), and tomato ('Beefsteak') in the greenhouse using previously described procedures (Bhat and Subbarao 1999; Hayes et al. 2011a; Vallad et al. 2006). Experiments were conducted two times. Thirty seeds of each host were sown in 200-well plug trays (Hummert International, St. Louis) filled with Sunshine Mix number 4 (Sun Gro Horticulture, Canada). Three weeks after sowing, seedlings were transferred into 0.5-liter foam-insulated cups filled with a pasteurized sand-potting soil

Table 1. Statistical analysis of variance based on the effect of individual isolates of Verticillium dahliae, V. isaacii, and V. klebahnii on the ranked means of Verticillium wilt severity on different hosts across two independent experiments

\begin{tabular}{lrrrr}
\hline Effect & df $_{\text {Num }}$ & df $_{\text {Den }}$ & ATS & $\boldsymbol{P}$ value \\
\hline Experiment & 1.37 & 1 & 8.85 & 0.2189 \\
Isolate & 8.99 & 1 & 32.00 & 0.1364 \\
Host & 6.56 & 302 & 99.07 & $<0.0001$ \\
Isolate $\times$ host & 59.10 & 302 & 4.13 & $<0.0001$ \\
\hline
\end{tabular}

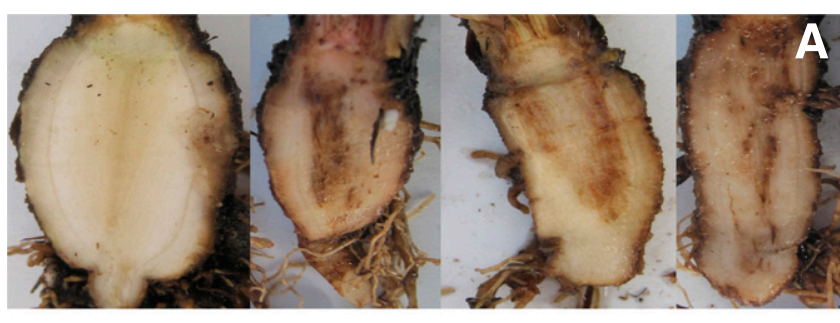

Control

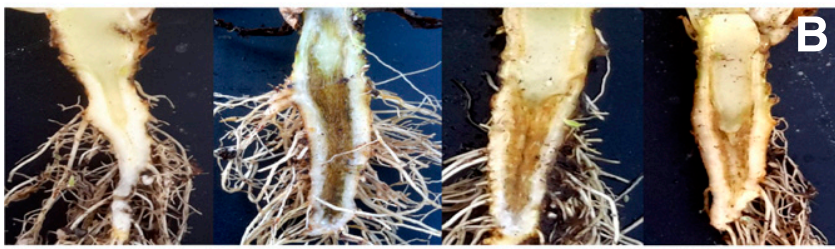

Control

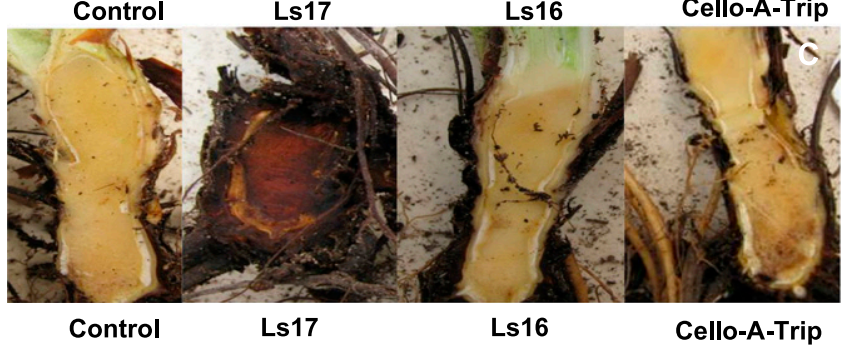

Fig. 1. Vascular discoloration in A, artichoke; B, lettuce; and C, strawberry caused by the race 1 and 2 strains of Verticillium dahliae (Vd.Ls16 and Vd.Ls17) and an isolate of $\mathrm{V}$. isaacii (Cello-A-Tri-P) relative to an uninoculated control plant. mixture $(2: 1, \mathrm{vol} / \mathrm{vol})$. Strawberry transplants were first established in trays containing the potting mix; after dormancy was broken and the plants had grown leaves and new roots, plants were then transplanted for inoculation. Each host-isolate treatment combination was replicated three times, with 10 plants in each replication, and was arranged in a randomized complete block design. Inoculum from all $V$. dahliae, $V$. isaacii, and $V$. klebahnii isolates were prepared as previously described by Vallad et al. (2006). Seedlings were inoculated at 4 weeks after sowing by saturating the soil in each well with a 5- to 10-ml suspension containing $1 \times$ $10^{7}$ conidia $/ \mathrm{ml}$ in sterile distilled water. Two additional inoculations were performed on all plants with the corresponding inoculum at 1 and 2 weeks after the first inoculation. Control plants for each host were mock inoculated with sterile distilled water and were kept in a separate block. Plants were incubated on greenhouse benches for approximately 10 weeks after the first inoculations and were evaluated for Verticillium wilt severity. Each plant was uprooted gently; roots were washed free of soil, and cut longitudinally to evaluate disease severity. Verticillium wilt severity was assessed as previously described by Vallad et al. (2006). Briefly, root discoloration was rated on a 0 -to- 5 scale, where $0=$ no vascular discoloration; $1=1$ to $25 \%$ of the vascular tissue exhibiting discoloration; $2=26$ to $50,3=51$ to 75 , and $4=76$ to $100 \%$ discoloration and no foliar symptoms; and $5=100 \%$ discoloration and the presence of foliar symptoms typical of Verticillium wilt.

Symptomatic root and crown tissues were washed, surface sterilized using distilled water and 5\% bleach, dissected, and plated on NP-10 medium (Kabir et al. 2004). After 10 to 14 days of incubation at 22 to $24^{\circ} \mathrm{C}$, plates were examined under a dissecting microscope for the presence of microsclerotia, verticillate conidiophores, and hyaline conidia, the distinguishing characteristics of Verticillium spp.

Evaluation of $V$. dahliae race 1-resistant and race 2-partially resistant lettuce cultivars against $V$. isaacii and $V$. klebahnii. Eight $V$. dahliae race 1-resistant cultivars ('Annapolis', 'Eruption', 'Defender', 'Pavane', 'Little Gem', 'Sentry', 'Infantry', and 'Merlot'; Hayes et al. 2007), and four $V$. dahliae race 2-partially resistant accessions (169511, 171674, 204707, and 226641; Hayes et al. 2011a) were tested against two isolates of $V$. isaacii (Cello-A-Tri-P and PD341), two isolates of V. klebahnii (PD458 and PD659), and a race 1 (Ls. 16) and race 2 (Ls. 17) isolate of $V$. dahliae. Isolate Cello-A-Tri-P was previously known to be pathogenic while isolates PD 341, PD 458, and PD 659 were determined to be pathogenic on strawberry from the pathogenicity assays described above.

All plant growth conditions, inoculum preparation, inoculation, and disease scoring were the same as described above. Lettuce cultivar-isolate combinations were arranged in a randomized complete block design with three replications, and each replication included 10 plants of each lettuce line. The experiment was repeated twice.

Data analysis. Disease severity data from the greenhouse studies were analyzed using analysis of variance (ANOVA)-type statistics of ranked data using the PROC Mixed procedure in SAS (SAS Institute, Cary, NC), and the LD_CI macro was used to generate relative marginal effects for each treatment and $95 \%$ confidence intervals for detection of statistical difference between treatments (Shah and Madden 2004). Orthogonal contrasts were conducted to compare the disease levels caused by $V$. isaacii and $V$. klebahnii (at the species level with data from all species combined) with $V$. dahliae races 1 and 2 on crops in which individual isolates were pathogenic, as well as between the two races. This was done to verify whether the general response of $V$. isaacii and $V$. klebahnii aligned with race 1 or 2 of $V$. dahliae.

\section{Results}

ANOVA indicated no significant differences between the two experiments (Table 1); thus, the data from the two experiments were combined. ANOVA indicated no significant differences among isolates of V. isaacii V. klebahnii, and V. dahliae. Most of the V. klebahnii and $V$. isaacii isolates did not cause Verticillium wilt symptoms on most hosts evaluated. Correspondingly, significant interactions were observed among hosts and isolate-host interactions (Table 1).

Pathogenicity on artichoke. Artichoke plants inoculated with V. dahliae isolates (Ls. 16 and Ls. 17) exhibited root discoloration (Fig. 1A). Plants were significantly stunted and had dry leaves relative 
to noninoculated plants. Similarly, V. isaacii (Cello-A-Tri-P, PD 341, PD 661, and PD 752) and V. klebahnii (PD 347, PD 407, PD 458, and PD 659) also produced root discoloration. $V$. isaacii isolate Cello-A-Tri-P produced higher disease severities than the $V$. dahliae race 1 isolate Ls.16 (Table 2). Overall, mean ratings of disease severity caused by isolates of $V$. dahliae were higher than those caused by

Table 2. Median and maximum disease severity and relative marginal effects along with 95\% confidence intervals (CI) for Verticillium wilt severity ratings in relation to different hosts and isolates of Verticillium dahliae, $V$. isaacii, and V. klebahnii

\begin{tabular}{|c|c|c|c|c|}
\hline \multirow[b]{2}{*}{ Hosts, isolates ${ }^{c}$} & \multicolumn{2}{|c|}{ Disease severity $^{a}$} & \multicolumn{2}{|c|}{$\begin{array}{c}\text { Relative marginal } \\
\text { effect }^{\mathbf{b}}\end{array}$} \\
\hline & Median & Maximum & Estimate & $95 \% \mathrm{CI}$ \\
\hline \multicolumn{5}{|c|}{ Artichoke (5473/91 black) } \\
\hline Ls.16 & 1.43 & 2.50 & 0.69 & $(0.57,0.79)$ \\
\hline Ls.17 & 2.75 & 3.50 & 0.92 & $(0.83,0.94)$ \\
\hline Cello-A-Tri-P & 2.00 & 2.43 & 0.71 & $(0.57,0.81)$ \\
\hline PD 341 & 0.92 & 1.29 & 0.46 & $(0.32,0.60)$ \\
\hline PD 661 & 0.47 & 1.14 & 0.33 & $(0.20,0.49)$ \\
\hline PD 752 & 0.31 & 1.40 & 0.36 & $(0.24,0.52)$ \\
\hline PD 347 & 0.69 & 2.17 & 0.45 & $(0.24,0.68)$ \\
\hline PD 407 & 0.32 & 1.67 & 0.37 & $(0.17,0.65)$ \\
\hline PD 458 & 0.21 & 1.86 & 0.34 & $(0.19,0.55)$ \\
\hline PD 659 & 0.34 & 2.29 & 0.37 & $(0.18,0.63)$ \\
\hline \multicolumn{5}{|c|}{ Cauliflower (Snowball) } \\
\hline Ls.16 & 0.37 & 0.70 & 0.59 & $(0.39,0.75)$ \\
\hline Ls. 17 & 0.57 & 1.00 & 0.62 & $(0.36,0.82)$ \\
\hline Cello-A-Tri-P & 0.05 & 0.60 & 0.42 & $(0.24,0.62)$ \\
\hline PD 341 & 0.58 & 1.30 & 0.65 & $(0.42,0.81)$ \\
\hline PD 661 & 0.00 & 1.22 & 0.37 & $(0.19,0.62)$ \\
\hline PD 752 & 0.05 & 0.33 & 0.36 & $(0.23,0.51)$ \\
\hline PD 347 & 0.50 & 1.25 & 0.64 & $(0.40,0.82)$ \\
\hline PD 407 & 0.00 & 1.33 & 0.41 & $(0.20,0.67)$ \\
\hline PD 458 & 0.27 & 0.44 & 0.47 & $(0.31,0.64)$ \\
\hline PD 659 & 0.15 & 1.22 & 0.48 & $(0.26,0.70)$ \\
\hline \multicolumn{5}{|c|}{ Eggplant (Long purple) } \\
\hline Ls. 16 & 1.17 & 2.14 & 0.78 & $(0.64,0.86)$ \\
\hline Ls. 17 & 4.15 & 5.00 & 0.95 & $(0.63,0.99)$ \\
\hline Cello-A-Tri-P & 0.05 & 0.80 & 0.32 & $(0.17,0.54)$ \\
\hline PD 341 & 0.39 & 1.29 & 0.54 & $(0.36,0.70)$ \\
\hline PD 661 & 0.10 & 0.60 & 0.37 & $(0.20,0.59)$ \\
\hline PD 752 & 0.26 & 0.56 & 0.43 & $(0.26,0.62)$ \\
\hline PD 347 & 0.16 & 0.30 & 0.34 & $(0.22,0.49)$ \\
\hline PD 407 & 0.15 & 0.56 & 0.37 & $(0.21,0.58)$ \\
\hline PD 458 & 0.31 & 0.89 & 0.5 & $(0.33,0.68)$ \\
\hline PD 659 & 0.11 & 0.70 & 0.41 & $(0.23,0.62)$ \\
\hline \multicolumn{5}{|l|}{ Lettuce (Salinas) } \\
\hline Ls.16 & 3.00 & 3.50 & 0.81 & $(0.67,0.89)$ \\
\hline Ls. 17 & 4.50 & 4.67 & 0.85 & $(0.74,0.91)$ \\
\hline Cello-A-Tri-P & 3.26 & 3.96 & 0.69 & $(0.54,0.80)$ \\
\hline PD 341 & 1.00 & 3.00 & 0.41 & $(0.23,0.62)$ \\
\hline PD 661 & 1.75 & 3.13 & 0.53 & $(0.32,0.73)$ \\
\hline PD 752 & 0.75 & 2.13 & 0.29 & $(0.14,0.52)$ \\
\hline \multirow[t]{2}{*}{ PD 347} & 1.04 & 1.78 & 0.31 & $(0.17,0.51)$ \\
\hline & & & \multicolumn{2}{|c|}{ (continued in next column) } \\
\hline
\end{tabular}

a Disease severity of Verticillium wilt was assessed visually on an ordinal 0to- 5 scale, where $0=$ no vascular discoloration; $1=1$ to $25 \%$ of the vascular tissue showing discoloration; $2=26$ to $50,3=51$ to 75 , and $4=76$ to $100 \%$ discoloration with no foliar symptoms; and $5=100 \%$ discoloration and the presence of foliar symptoms typical of Verticillium wilt (Vallad et al. 2006). Analysis of variance indicated no significant differences between two experiments, and therefore averaged disease severity from the two experiments are shown. Median values were calculated from wilt severity values averaged over inoculated plants within replications.

b Relative marginal effect and 95\% CI are calculated from analysis of the rank values of the disease severity data.

c $V$. dahliae isolates are Ls.16 and Ls.17 (lettuce); V. isaacii isolates are Cello-A-Tri-P (spinach), PD 341 (lettuce), PD 661 (lettuce), and PD 752 (spinach); and V. klebahnii isolates are PD 347 (artichoke), PD 407 (lettuce), PD 458 (lettuce), and PD 659 (lettuce).
V. isaacii and V. klebahnii (Table 2). V. dahliae and V. isaacii were successfully reisolated from the discolored roots of the infected artichoke plants.

Pathogenicity on cauliflower. Cauliflower plants inoculated with V. dahliae isolates (Ls. 16 and Ls. 17), V. isaacii (Cello-A-Tri-P, PD 341, PD 661, and PD 752), and V. klebahnii (PD 347, PD 407, PD

Table 2. (continued from preceding column)

\begin{tabular}{|c|c|c|c|c|}
\hline \multirow[b]{2}{*}{ Hosts, isolates ${ }^{c}$} & \multicolumn{2}{|c|}{ Disease severity ${ }^{\mathbf{a}}$} & \multicolumn{2}{|c|}{$\begin{array}{c}\text { Relative marginal } \\
\text { effect }^{\mathbf{b}}\end{array}$} \\
\hline & Median & Maximum & Estimate & $95 \% \mathrm{CI}$ \\
\hline PD 407 & 1.05 & 2.33 & 0.36 & $(0.21,0.55)$ \\
\hline PD 458 & 1.25 & 2.17 & 0.46 & $(0.28,0.66)$ \\
\hline PD 659 & 0.95 & 1.50 & 0.3 & $(0.20,0.43)$ \\
\hline \multicolumn{5}{|c|}{ Lettuce (La Brillante) } \\
\hline Ls.16 & 0.00 & 0.00 & 0.00 & $(0.00,0.00)$ \\
\hline Ls. 17 & 2.93 & 4.78 & 0.87 & $(0.75,0.92)$ \\
\hline Cello-A-Tri-P & 1.19 & 1.38 & 0.63 & $(0.41,0.79)$ \\
\hline PD 341 & 1.13 & 1.30 & 0.59 & $(0.45,0.72)$ \\
\hline PD 661 & 1.00 & 1.50 & 0.32 & $(0.19,0.48)$ \\
\hline PD 752 & 1.04 & 1.60 & 0.32 & $(0.29,0.49)$ \\
\hline PD 347 & 1.36 & 1.50 & 0.42 & $(0.23,0.65)$ \\
\hline PD 407 & 1.25 & 1.86 & 0.47 & $(0.24,0.72)$ \\
\hline PD 458 & 0.66 & 1.13 & 0.18 & $(0.12,0.30)$ \\
\hline PD 659 & 1.42 & 1.50 & 0.47 & $(0.30,0.65)$ \\
\hline
\end{tabular}

Pepper (California

$$
\text { Wonder) }
$$

$$
\text { Ls. } 16
$$

Ls. 17

Cello-A-Tri-P

PD 341

PD 661

PD 752

PD 347

PD 407

PD 458

PD 659

Spinach (Hector)

Ls. 16

Ls. 17

Cello-A-Tri-P

PD 341

PD 661

PD 752

PD 347

PD 407

PD 458

PD 659

Strawberry (Albion)

Ls. 16

Ls. 17

Cello-A-Tri-P

PD 341

PD 661

PD 752

PD 347

PD 407

PD 458

PD 659

Tomato (Beefsteak)

$$
\text { Ls. } 16
$$

Ls. 17

Cello-A-Tri-P

PD 341

PD 661

PD 752

PD 347

PD 407

PD 458

PD 659

$\begin{array}{llll}0.13 & 0.20 & 0.65 & (0.46,0.80) \\ 0.00 & 0.00 & 0.35 & (0.30,0.40) \\ 0.00 & 0.40 & 0.53 & (0.33,0.71) \\ 0.00 & 0.00 & 0.35 & (0.30,0.40) \\ 0.00 & 0.10 & 0.47 & (0.34,0.61) \\ 0.00 & 0.00 & 0.35 & (0.30,0.40) \\ 0.00 & 0.56 & 0.55 & (0.33,0.75) \\ 0.33 & 0.44 & 0.71 & (0.46,0.86) \\ 0.11 & 0.60 & 0.69 & (0.45,0.85) \\ 0.00 & 0.00 & 0.35 & (0.30,0.40) \\ & & & \\ 4.10 & 5.00 & 0.93 & (0.87,0.94) \\ 3.70 & 4.20 & 0.86 & (0.81,0.89) \\ 0.00 & 0.20 & 0.22 & (0.15,0.31) \\ 1.50 & 3.00 & 0.65 & (0.48,0.79) \\ 0.00 & 0.80 & 0.32 & (0.36,0.48) \\ 0.00 & 0.10 & 0.30 & (0.32,0.46) \\ 0.40 & 1.40 & 0.46 & (0.47,0.63) \\ 0.50 & 0.60 & 0.42 & (0.31,0.56) \\ 0.50 & 1.20 & 0.49 & (0.32,0.62) \\ 0.20 & 1.40 & 0.37 & (0.42,0.54) \\ & & & \\ 2.20 & 2.60 & 0.39 & (0.20,0.44) \\ 4.25 & 5.00 & 0.93 & (0.89,0.95) \\ 2.13 & 2.40 & 0.40 & (0.27,0.50) \\ 2.00 & 2.40 & 0.31 & (0.30,0.47) \\ 2.38 & 3.40 & 0.50 & (0.31,0.69) \\ 2.22 & 3.60 & 0.46 & (0.25,0.69) \\ 2.85 & 3.40 & 0.71 & (0.62,0.78) \\ 2.55 & 3.00 & 0.57 & (0.43,0.70) \\ 2.10 & 2.80 & 0.35 & (0.21,0.52) \\ 2.20 & 3.40 & 0.47 & (0.30,0.67) \\ & & & \\ 1.46 & 2.80 & 0.81 & (0.58,0.90) \\ 2.81 & 3.50 & 0.92 & (0.87,0.94) \\ 0.00 & 0.43 & 0.45 & (0.33,0.58) \\ 0.00 & 0.17 & 0.44 & (0.33,0.56) \\ 0.00 & 0.00 & 0.38 & (0.34,0.41) \\ 0.00 & 0.22 & 0.44 & (0.33,0.56) \\ 0.00 & 0.00 & 0.38 & (0.34,0.41) \\ 0.00 & 0.00 & 0.38 & (0.34,0.41) \\ 0.00 & 0.00 & 0.38 & (0.34,0.41) \\ 0.00 & 0.25 & 0.44 & (0.33,0.57) \\ & & & \end{array}$


458, and PD 659) exhibited no or negligible root discoloration (Table 2). Plants looked healthy and disease severity was no different from that on control plants (data not shown). Median disease severity for all isolates and species varied between 0.0 and 0.58 (Table 2).

Pathogenicity on eggplant. Eggplants inoculated with V. dahliae isolate Ls. 17 exhibited severe root discoloration in most plants as well as stunting and dried leaves relative to noninoculated plants. However, V. isaacii (Cello-A-Tri-P, PD 341, PD 661, and PD 752) and V. klebahnii (PD 347, PD 407, PD 458, and PD 659) produced little or no root discoloration. Overall, mean ratings of disease severity caused by isolates of $V$. dahliae were higher than those caused by $V$. isaacii and $V$. klebahnii, with the highest median disease severity of 4.15 for plants inoculated with V. dahliae Ls. 17 (Table 2).

Pathogenicity on Salinas and La Brillante lettuce. Plants of cultivar Salinas inoculated with $V$. dahliae isolates Ls. 16 and Ls. 17 exhibited root discoloration (Fig. 1B), as did the plants inoculated with $V$. isaacii (Cello-A-Tri-P, PD 341, PD 661, and PD 752) and V. klebahnii (PD 347, PD 407, PD 458, and PD 659). Of the V. isaacii isolates, Cello-A-Tri-P induced disease severity similar to $V$. dahliae isolate Ls. 16 (Fig. 1B). Further, V. dahliae and V. isaacii were successfully reisolated from the discolored tap roots of the infected Salinas. Overall, median ratings of disease severity produced by isolates of $V$. dahliae were greater than those caused by $V$. isaacii and V. klebahnii. Roots of La Brillante inoculated with V. dahliae isolate Ls. 17 were discolored and the plants displayed wilting symptoms; however, there was no vascular discoloration in plants inoculated with $V$. dahliae isolate Ls. 16. Even though plants of La Brillante inoculated with $V$. isaacii and $V$. klebahnii isolates displayed vascular discoloration, they had low disease severity ratings (Table 2 ). In general, median ratings of disease severity produced by isolates of $V$. dahliae were greater than those caused by $V$. isaacii and V. klebahnii (Table 2).

Pathogenicity on pepper. All of the $V$. dahliae, $V$. isaacii, or $V$. klebahnii isolates evaluated in this study caused negligible to no vascular discoloration on pepper (Table 2). Plants looked healthy and disease severity scores between inoculated and noninoculated control plants were not statistically different (data not shown).

Pathogenicity on spinach. Spinach plants inoculated with $V$. dahliae isolates Ls. 16 and Ls. 17 showed root discoloration. However, none of the plants inoculated with $V$. isaacii (Cello-A-Tri-P, PD 341,

Table 3. Orthogonal contrasts between Verticillium isaacii and V. klebahnii and type isolates for races 1 (Ls.16) and 2 (Ls.17) of V. dahliae on hosts in which the two former species caused Verticillium wilt

\begin{tabular}{|c|c|c|c|c|}
\hline Contrasts & $\begin{array}{c}\text { Numerator } \\
\text { DF }\end{array}$ & $\begin{array}{c}\text { Denominator } \\
\text { DF }\end{array}$ & $\boldsymbol{F}$ & $P>F$ \\
\hline \multicolumn{5}{|l|}{ Artichoke } \\
\hline Ls.16 versus $V$. isaacii & 1 & 48 & 6.26 & 0.0158 \\
\hline Ls. 16 versus $V$. klebahnii & 1 & 48 & 12.98 & 0.0007 \\
\hline Ls. 16 versus Ls. 17 & 1 & 48 & 7.02 & $<0.0109$ \\
\hline Ls. 17 versus $V$. isaacii & 1 & 48 & 64.08 & $<0.0001$ \\
\hline Ls.17 versus V. klebahnii & 1 & 48 & 119.11 & $<0.0001$ \\
\hline \multicolumn{5}{|l|}{ Lettuce (Salinas) } \\
\hline Ls. 16 versus $V$. isaacii & 1 & 48 & 14.18 & 0.0005 \\
\hline Ls. 16 versus $V$. klebahnii & 1 & 48 & 34.15 & $<0.0001$ \\
\hline Ls. 16 versus Ls. 17 & 1 & 48 & 0.32 & 0.5717 \\
\hline Ls. 17 versus $V$. isaacii & 1 & 48 & 33.85 & $<0.0001$ \\
\hline Ls.17 versus $V$. klebahnii & 1 & 48 & 103.87 & $<0.0001$ \\
\hline \multicolumn{5}{|l|}{ Lettuce (La Brillante) } \\
\hline Ls. 16 versus $V$. isaacii & 1 & 48 & 6.94 & 0.0113 \\
\hline Ls. 16 versus $V$. klebahnii & 1 & 48 & 11.76 & 0.0013 \\
\hline Ls. 16 versus Ls. 17 & 1 & 48 & 130.63 & $<0.0001$ \\
\hline Ls. 17 versus $V$. isaacii & 1 & 48 & 18.72 & $<0.0001$ \\
\hline Ls.17 versus $V$. klebahnii & 1 & 48 & 26.76 & $<0.0001$ \\
\hline \multicolumn{5}{|l|}{ Strawberry } \\
\hline Ls. 16 versus $V$. isaacii & 1 & 66 & 1.75 & 0.1910 \\
\hline Ls. 16 versus $V$. klebahnii & 1 & 66 & 5.80 & 0.0188 \\
\hline Ls. 16 versus Ls. 17 & 1 & 66 & 56.83 & $<0.0001$ \\
\hline Ls. 17 versus $V$. isaacii & 1 & 66 & 144.90 & $<0.0001$ \\
\hline Ls. 17 versus $V$. klebahnii & 1 & 66 & 56.29 & $<0.0001$ \\
\hline
\end{tabular}

PD 661, and PD 752) or V. klebahnii (PD 347, PD 407, PD 458, and PD 659) exhibited symptoms associated with Verticillium wilt. Overall, median disease ratings of $V$. dahliae were higher than those caused by $V$. isaacii and V. klebahnii (Table 2).

Pathogenicity on strawberry. All plants inoculated with $V$. dahliae, $V$. isaacii, and V. klebahnii showed Verticillium wilt symptoms to varying degrees (Fig. 1C). The disease severity ratings for all isolates of V. isaacii and V. klebahnii were above the minimum severity rating of 2.0 associated with isolates pathogenic on individual hosts. Overall, median disease severity ratings caused by the race 2 isolate of $V$. dahliae were higher than those produced by $V$. isaacii and $V$. klebahnii. However, all isolates of $V$. isaacii and V. klebahnii, including the race 1 isolate of $V$. dahliae, caused lesser disease than V. dahliae race 2 isolate Ls. 17 (Table 2).

Pathogenicity on tomato. On Beefsteak tomato, only V. dahliae isolate Ls. 17 caused vascular discoloration and wilting symptoms. Isolate Ls. 16 showed only slight discoloration and no wilting was observed (Table 2). However, none of the $V$. isaacii and V. klebahnii isolates caused any symptoms associated with Verticillium wilt (Table 2).

Contrasts between $V$. isaacii, V. klebahnii, and the two races of $V$. dahliae. Except for the contrast between race 1 of $V$. dahliae (Ls. 16 versus $V$. isaacii; Table 3 ) and $V$. isaacii, all other contrasts between $V$. isaacii and $V$. klebahnii and the two races of $V$. dahliae were significant, suggesting that disease severities caused by these two species were either higher or lower than those of the two races of $V$. dahliae (Table 3). Except for one isolate of $V$. isaacii on artichoke and all isolates of both $V$. isaacii and V. klebahnii on both cultivars of lettuce, the disease severities were lower than those caused by both races of $V$. dahliae (Tables 2 and 3). In strawberry, however, nearly all isolates of $V$. isaacii and $V$. klebahnii caused as much or higher disease severities than the race 1 isolate of $V$. dahliae (Tables 2 and 3). By far, the most virulent isolate on all hosts was race 2 (Ls. 17) of $V$. dahliae (Tables 2 and 3 ).

Evaluation of $V$. isaacii isolates on $V$. dahliae race 1-resistant and $V$. dahliae race 2-partially resistant lettuce cultivars. $V$. isaacii isolate PD 341 and V. klebahnii isolates (PD 458 and PD 659) failed to produce Verticillium wilt symptoms on susceptible Salinas. However, V. isaacii isolate Cello-A-Tri-P induced obvious disease symptoms on Salinas but failed to produce any disease symptoms on the other $V$. dahliae-resistant and partially resistant lettuce cultivars (Table 4).

\section{Discussion}

The current study explored the host range of two recently described Verticillium spp. (Inderbitzin et al. 2011) from artichoke, spinach, and lettuce fields in coastal California. Of the four isolates each of $V$. isaacii and $V$. klebahnii evaluated in this study, only one isolate of $V$. isaacii was pathogenic on the lettuce cultivar susceptible to both $V$. dahliae races 1 and 2 and artichoke. This is the first demonstration of Koch's postulates for $V$. isaacii on lettuce in California. On other hosts evaluated in this study, all isolates of these two species were nonpathogenic, except on strawberry. All eight isolates were highly pathogenic on strawberry. In addition, the effectiveness of $V$. dahliae race 1 resistance and partial race 2 resistance in lettuce cultivars and accessions was tested using two isolates each of $V$. isaacii and $V$. klebahnii identified as pathogenic on strawberry and a susceptible lettuce cultivar. All lettuce lines tested were resistant to $V$. isaacii and $V$. klebahnii. It is evident from this study that some of the $V$. isaacii isolates, including Cello-A-Tri-P, can cause disease at levels similar to $V$. dahliae race 1 isolate Ls. 16 on certain lettuce cultivars. Some of these lettuce cultivars, including PI 169511, PI 171674 , PI 204707, and PI 226641, developed wilt symptoms following inoculations with $V$. dahliae race 1 isolate Ls. 16 (G. Sandoya, unpublished). Assuming that Ls. 16 and some of the $V$. isaacii isolates cause similar levels of disease, future inoculations with these isolates on some of these lettuce cultivars might result in low levels of disease symptoms in some experiments. Thus, at least some isolates in populations of $V$. isaacii and $V$. klebahnii could potentially become significant pathogens of some coastal California crops if clonal expansion of 
pathogenic genotype occurs (Gurung et al. 2014). However, resistance developed against $V$. dahliae (Hayes et al. 2007, 2011a) also offers resistance against these other Verticillium spp.

Knowledge of the genotypic and pathogenic variation that exists within Verticillium spp. present in a particular agricultural region is beneficial to research programs with the goal of developing appropriate

Table 4. Median and maximum disease severity and relative marginal effects along with $95 \%$ confidence intervals (CI) for Verticillium wilt severity ratings in relation to different isolates of Verticillium isaacii, V. klebahnii, and V. dahliae on lettuce cultivars resistant to $V$. dahliae race 1 and partially resistant to $V$. dahliae race 2 isolates

\begin{tabular}{|c|c|c|c|c|c|c|c|}
\hline \multirow[b]{2}{*}{ Isolates, cultivars ${ }^{\mathrm{b}}$} & \multicolumn{3}{|c|}{ Relative marginal effects ${ }^{\mathbf{a}}$} & \multirow{2}{*}{\multicolumn{4}{|c|}{$\begin{array}{l}\text { lates tested were weak pathogens, the potential for substantial eco- } \\
\text { nomic losses caused by certain isolates of these species must not }\end{array}$}} \\
\hline & Median & Estimate & $95 \% \mathrm{CI}$ & \multirow{2}{*}{\multicolumn{4}{|c|}{$\begin{array}{l}\text { be overlooked. Species of Verticillium are long-term soil residents } \\
\text { and survive in field soil as resting structures. Little is known about }\end{array}$}} \\
\hline \multicolumn{4}{|l|}{ Cello-A-Tri-P } & & & & \\
\hline 169511 & 0.00 & 0.35 & $(0.32,0.37)$ & \multicolumn{4}{|c|}{ the population structure of $V$. isaacii and V. klebahnii in field soils } \\
\hline 171674 & 0.00 & 0.47 & $(034,0.62)$ & \multicolumn{4}{|c|}{ but we speculate that, under certain circumstances, severe diseases } \\
\hline 204707 & 0.00 & 0.49 & $(0.33,0.64)$ & \multirow{2}{*}{\multicolumn{4}{|c|}{$\begin{array}{l}\text { in lettuce or artichoke fields could occur if successful virulent geno- } \\
\text { types are selected. Nevertheless, compared with } V \text {. dahliae, } V \text {. isaaci }\end{array}$}} \\
\hline 226641 & 0.00 & 0.41 & $(0.30,0.53)$ & & & & \\
\hline Annapolis & 0.20 & 0.55 & $(0.38,0.71)$ & \\
\hline Defender & 0.70 & 0.72 & $(0.55,0.84)$ & \multirow{2}{*}{\multicolumn{4}{|c|}{ Table 4. (continued from preceding column) }} \\
\hline Eruption & 0.00 & 0.35 & $(0.32,0.37)$ & & & & \\
\hline Infantry & 0.00 & 0.35 & $(0.32,0.37)$ & \multirow[b]{2}{*}{ Isolates, cultivars ${ }^{\mathbf{b}}$} & \multicolumn{3}{|c|}{ Relative marginal effects $^{\mathbf{a}}$} \\
\hline $\begin{array}{l}\text { La Brillante } \\
\text { Little Gem }\end{array}$ & $\begin{array}{l}0.20 \\
0.20\end{array}$ & $\begin{array}{l}0.56 \\
0.55\end{array}$ & $\begin{array}{l}(0.38,0.72) \\
(0.38,0.71)\end{array}$ & & Median & Estimate & $95 \% \mathrm{CI}$ \\
\hline Merlot & 0.00 & 0.47 & $(0.34,0.62)$ & \multicolumn{4}{|l|}{ PD 659} \\
\hline Pavane & 0.00 & 0.47 & $(0.34,0.62)$ & 169511 & 0.00 & 0.47 & $(0.32,0.63)$ \\
\hline Salinas & 2.70 & 0.83 & $(0.82,0.84)$ & 171674 & 0.00 & 0.35 & $(0.32,0.37)$ \\
\hline Sentry & 0.00 & 0.35 & $(0.32,0.37)$ & 204707 & 0.00 & 0.35 & $(0.32,0.37)$ \\
\hline \multicolumn{4}{|l|}{ PD 341} & 226641 & 0.00 & 0.35 & $(0.32,0.37)$ \\
\hline 169511 & 0.00 & 0.47 & $(0.33,0.63)$ & Annapolis & 0.20 & 0.54 & $(0.37,0.70)$ \\
\hline 171674 & 0.00 & 0.35 & $(0.32,0.37)$ & Defender & 0.00 & 0.35 & $(0.32,0.37)$ \\
\hline 204707 & 0.00 & 0.49 & $(0.33,0.65)$ & Eruption & 0.00 & 0.35 & $(0.32,0.37)$ \\
\hline 226641 & 0.00 & 0.41 & $(0.30,0.54)$ & Infantry & 0.00 & 0.35 & $(0.32,0.37)$ \\
\hline Annapolis & 0.00 & 0.41 & $(0.29,0.54)$ & La Brillante & 0.00 & 0.35 & $(0.32,0.37)$ \\
\hline Defender & 0.00 & 0.41 & $(0.29,0.54)$ & Little Gem & 0.00 & 0.35 & $(0.32,0.37)$ \\
\hline Eruption & 0.00 & 0.35 & $(0.32,0.37)$ & Merlot & 0.00 & 0.35 & $(0.32,0.37)$ \\
\hline Infantry & 0.00 & 0.49 & $(0.33,0.65)$ & Pavane & 0.00 & 0.35 & $(0.32,0.37)$ \\
\hline La Brillante & 0.00 & 0.35 & $(0.32,0.37)$ & Salinas & 0.00 & 0.49 & $(0.32,0.65)$ \\
\hline Little Gem & 0.00 & 0.35 & $(0.32,0.37)$ & Sentry & 0.00 & 0.47 & $(0.32,0.63)$ \\
\hline Merlot & 0.00 & 0.41 & $(0.30,0.53)$ & \multicolumn{4}{|l|}{ Ls. 16} \\
\hline Pavane & 0.00 & 0.41 & $(0.30,0.53)$ & 169511 & 0.00 & 0.35 & $(0.32,0.37)$ \\
\hline Salinas & 0.00 & 0.49 & $(0.33,0.65)$ & 171674 & 0.00 & 0.35 & $(0.32,0.37)$ \\
\hline Sentry & 0.00 & 0.35 & $(0.32,0.37)$ & 204707 & 0.00 & 0.35 & $(0.32,0.37)$ \\
\hline \multicolumn{4}{|l|}{ PD 458} & 226641 & 0.00 & 0.50 & $(0.32,0.67)$ \\
\hline 169511 & 0.00 & 0.47 & $(0.32,0.63)$ & Annapolis & 0.00 & 0.41 & $(0.29,0.54)$ \\
\hline 171674 & 0.00 & 0.41 & $(0.29,0.54)$ & Defender & 0.00 & 0.41 & $(0.29,0.54)$ \\
\hline 204707 & 0.00 & 0.35 & $(0.32,0.37)$ & Eruption & 0.00 & 0.35 & $(0.32,0.37)$ \\
\hline 226641 & 0.00 & 0.35 & $(0.32,0.37)$ & Infantry & 0.00 & 0.35 & $(0.32,0.37)$ \\
\hline Annapolis & 0.00 & 0.47 & $(0.33,0.63)$ & La Brillante & 0.00 & 0.35 & $(0.32,0.37)$ \\
\hline Defender & 0.00 & 0.35 & $(0.32,0.37)$ & Little Gem & 0.00 & 0.41 & $(0.29,0.54)$ \\
\hline Eruption & 0.00 & 0.42 & $(0.29,0.57)$ & Merlot & 0.00 & 0.42 & $(0.29,0.57)$ \\
\hline Infantry & 0.00 & 0.35 & $(0.32,0.37)$ & Pavane & 0.00 & 0.35 & $(0.32,0.37)$ \\
\hline La Brillante & 0.00 & 0.35 & $(0.32,0.37)$ & Salinas & 4.70 & 0.99 & $(0.98,0.99)$ \\
\hline Little Gem & 0.00 & 0.35 & $(0.32,0.37)$ & Sentry & 0.00 & 0.35 & $(0.32,0.37)$ \\
\hline Merlot & 0.00 & 0.49 & $(0.32,0.65)$ & \multicolumn{4}{|l|}{ Ls. 17} \\
\hline Pavane & 0.00 & 0.35 & $(0.32,0.37)$ & 169511 & 1.20 & 0.66 & $(0.45,0.82)$ \\
\hline Salinas & 0.20 & 0.56 & $(0.37,0.73)$ & 171674 & 2.00 & 0.67 & $(0.45,0.84)$ \\
\hline Sentry & 0.00 & 0.47 & $(0.32,0.63)$ & 204707 & 3.10 & 0.87 & $(0.85,0.89)$ \\
\hline & & (contin & next column) & 226641 & 4.00 & 0.93 & $(0.91,0.94)$ \\
\hline & & & & Annapolis & 3.80 & 0.90 & $(0.86,0.93)$ \\
\hline values of the disea & rity data. & ilated from & sis of the rank & Defender & 4.20 & 0.93 & $(0.89,0.96)$ \\
\hline b Isolate Cello-A-T & isaacii) & llected fron & nach plant in & Eruption & 3.80 & 0.91 & $(0.88,0.92)$ \\
\hline California. Isolate & +1 (V. isaa & $\mathrm{D} 458$ and $\mathrm{P}$ & V. klebahnii) & Infantry & 3.80 & 0.91 & $(0.87,0.94)$ \\
\hline were collected fro & tuce field $\mathrm{i}$ & ornia. $V . d a$ & solates Ls.16 & La Brillante & 4.30 & 0.93 & $(0.90,0.95)$ \\
\hline (race 1) and Ls.17 & ) were coll & rom Califor & were used as & Little Gem & 4.00 & 0.92 & $(0.90,0.94)$ \\
\hline controls. Lettuce & ars 16951 & 674,20470 & 226641 are & Merlot & 3.70 & 0.90 & $(0.87,0.93)$ \\
\hline partially resistant & hliae race 2 & es (Hayes et & 1a). Similarly, & Pavane & 4.20 & 0.93 & $(0.89,0.95)$ \\
\hline Annapolis, Defenc & iption, Infa & a Brillante, & Gem, Merlot, & Salinas & 4.50 & 0.96 & $(0.92,0.98)$ \\
\hline $\begin{array}{l}\text { Pavane, Salinas, ar } \\
\text { et al 2007). }\end{array}$ & ry are resis & V. dahliae ra & olates (Hayes & Sentry & 4.00 & 0.91 & $(0.88,0.93)$ \\
\hline
\end{tabular}

disease management strategies for that region, especially through resistance breeding. In the present study, V. isaacii and V. klebahnii collected from artichoke and lettuce fields were characterized for their pathogenicity and virulence on eight important crops. The results of this study showed that a majority of $V$. klebahnii and $V$. isaacii isolates exhibited little to no pathogenicity on most crops evaluated. However, one $V$. isaacii isolate, Cello-A-Tri-P, was pathogenic on the susceptible lettuce Salinas and artichoke. Not only did this finding demonstrate the pathogenicity of $V$. isaacii on these two crops but it also suggests that seemingly minor pathogens exhibit variation in aggressiveness under similar environmental conditions. Thus, although all of the V. klebahnii and three of four V. isaacii isolates tested were weak pathogens, the potential for substantial ecoand survive in field soil as resting structures. Little is known about the population structure of $V$. is in lettuce or artichoke fields could occur if successful virulent geno- 
and $V$. klebahnii appear to be generally less adapted to cause wilt disease in plants. The lack of susceptibility in other crops evaluated in this study suggests that $V$. isaacii may not pose a threat to these crops.

$V$. isaacii and $V$. klebahnii were unrecognized until Inderbitzin et al. (2011) defined these two new species from the previously described $V$. tricorpus based on multigene phylogenies. V. tricorpus had been reported as pathogenic to a number of important crops and ornamental plant species (Isaac 1953, 1967; Jabnoun-Khiareddine et al. 2006; Taylor 1968). Isaac (1953) inoculated sainfoin, potato, tomato, and snapdragon with $V$. tricorpus and found $V$. tricorpus to be pathogenic only on tomato. Similarly, Taylor (1968) reported V. tricorpus to be pathogenic on eggplant, hop, and tomato but not on alfalfa. Similarly, $V$. tricorpus from Tunisia had higher virulence to both tomato and eggplant (Jabnoun-Khiareddine et al. 2006). Recently, V. tricorpus was reported to be associated with Verticillium wilt in lettuce in Washington (Powell et al. 2013). However, based on the sequences of the internal transcribed spacer regions of ribosomal DNA of these $V$. tricorpus isolates (Vt.Ls.2010, Vt.Ls.2011-1, and Vt.Ls.2011-2) (Qin et al. 2008), the three isolates appear to be conspecific with $V$. isaacii. Therefore, it is quite likely that previously reported pathogenic isolates of $V$. tricorpus actually belong to either $V$. isaacii or $V$. klebahnii. Except for the isolates from Washington (Powell et al. 2013), other isolates were unavailable for characterization. Thus, $V$. isaacii and $V$. klebahnii could cause disease on multiple crops consistent with the host range reported in this study.

We also attempted to delineate the potential race structure among isolates from both $V$. isaacii and $V$. kelbahnii based on virulence of isolates on lettuce differentials relative to $V$. dahliae or the pattern of virulence exhibited by $V$. dahliae races on three crops on which $V$. isaacii or V. klebahnii isolates exhibited pathogenicity. This was done by virulence testing of multiple isolates of both species on the two differential lettuce lines routinely used to discriminate the two races in $V$. dahliae or inoculating all isolates of the three species on artichoke and strawberry. This was not a straightforward exercise, and the pattern of virulence exhibited depended on the host. Except on strawberry, isolates of $V$. isaacii and $V$. klebahnii exhibited lower virulence, collectively, than the two races of $V$. dahliae. However, one $V$. isaacii isolate (Cello-A-Tri-P) caused more severe symptoms than $V$. dahliae race 1 isolate in specific crops, including lettuce. In strawberry, however, isolates of both $V$. isaacii and V. klebahnii exhibited virulence intermediate to the two races of $V$. dahliae.

$V$. isaacii isolates associated with disease symptoms were reisolated from symptomatic lettuce plants of cultivar Salinas and artichoke on NP-10 medium (Kabir et al. 2004). More interestingly, isolates of $V$. isaacii and $V$. klebahnii were also reisolated from inoculated plants that remained asymptomatic throughout the experiments, including strawberry. It appears that, although the V. klebahnii isolates tested were nonpathogenic, they still colonized the root tissue like other pathogenic species such as V. dahliae and V. albo-atrum. Reisolation of nonpathogenic $V$. isaacii and $V$. klebahnii species from asymptomatic plants indicates that these fungi have the potential to reproduce on nonhosts and augment soil populations similar to the pathogenic isolates of $V$. dahliae.

In conclusion, of the $V$. klebahnii and $V$. isaacii isolates characterized in this study, only one isolate of $V$. isaacii was pathogenic on susceptible lettuce cultivar Salinas and artichoke. Thus, these species may represent potential threats to agriculture over the long term if field soils become densely infested with virulent isolates. However, resistance developed against races 1 and 2 of $V$. dahliae, at least in lettuce, should restrict the establishment and multiplication of these species in production systems.

\section{Acknowledgments}

Funding for this study was provided by USDA-NIFA-SCRI grant number 2010-51181-21069 and the California Leafy Greens Research Board. We thank R. Marchebout for her excellent technical assistance and K. Maruthachalam for assistance with strawberry experiments.

\section{Literature Cited}

Anonymous. 2011. 2011 Agricultural Statistics Annual. United States Department of Agriculture-National Agricultural Statistics Service. Online publication http://www.nass.usda.gov/Publications/Ag_Statistics/2011/index.asp

Anonymous. 2012. Agricultural Commissioner's Office Monterey County Crop Report 2011. http://www.co.monterey.ca.us/Home/ShowDocument?id=1481

Atallah, Z. K., Hayes, R. J., and Subbarao, K. V. 2011. Fifteen years of Verticillium wilt of lettuce in America's salad bowl: A tale of immigration, subjugation, and abatement. Plant Dis. 95:784-792.

Bhat, R., and Subbarao, K. 1999. Host range specificity in Verticillium dahliae. Phytopathology 89:1218-1225.

du Toit, L. J., Derie, M. L., and Hernandez-Perez, P. 2005. Verticillium wilt in spinach seed production. Plant Dis. 89:4-11.

Gurung, S., Short, D., Atallah, Z. K., and Subbarao, K. 2014. Clonal expansion of Verticillium dahliae in lettuce. Phytopathology 104:641-649.

Hayes, R. J., Maruthachalam, K., Vallad, G. E., Klosterman, S. J., and Subbarao, K. V. 2011a. Selection for resistance to Verticillium wilt caused by race 2 isolates of Verticillium dahliae in accessions of lettuce (Lactuca sativa L.). HortScience 46:201-206.

Hayes, R. J., McHale, L. K., Vallad, G. E., Truco, M. J., Michelmore, R. W., Klosterman, S. J., Maruthachalam, K., and Subbarao, K. V. 2011b. The inheritance of resistance to Verticillium wilt caused by race 1 isolates of Verticillium dahliae in the lettuce cultivar La Brillante. Theor. Appl. Genet. 123:509-517.

Hayes, R. J., Vallad, G. E., Qin, Q.-M., Grube, R. C., and Subbarao, K. V. 2007 Variation for resistance to Verticillium wilt in lettuce (Lactuca sativa L.). Plant Dis. 91:439-445.

Inderbitzin, P., Bostock, R. M., Davis, R. M., Usami, T., Platt, H. W., and Subbarao, K. V. 2011. Phylogenetics and taxonomy of the fungal vascular wilt pathogen Verticillium, with the descriptions of five new species. PLoS One 6:e28341.

Isaac, I. 1953. A further comparative study of pathogenic isolates of Verticillium: V. nubilum Pethybr. and V. tricorpus sp. nov. Trans. Br. Mycol. Soc. 36:180-182.

Isaac, I. 1967. Speciation in Verticillium. Annu. Rev. Phytopathol. 5:201-222.

Jabnoun-Khiareddine, H., Daami-Remadi, M., Hibar, K., Ayed, F., and El Mahjoub, M. 2006. Pathogenicity of Tunisian isolates of three Verticillium species on tomato and eggplant. Plant Pathol. J. 5:199-207.

Kabir, Z., Bhat, R. G., and Subbarao, K. V. 2004. Comparison of media for recovery of Verticillium dahliae from soil. Plant Dis. 88:49-55.

Koike, S. T., Subbarao, K. V., Davis, R. M., Gordon, T. R., and Hubbard, J. C 1994. Verticillium wilt of cauliflower in California. Plant Dis. 78:1116-1121.

Pegg, G. F., and Brady, B. L. 2002. Verticillium Wilts. CABI Publishing, New York.

Powell, M., Gundersen, B., Miles, C., Coats, K., and Inglis, D. A. 2013. First report of Verticillium wilt on lettuce (Lactuca sativa) in Washington caused by Verticillium tricorpus. Plant Dis. 97:996.

Qin, Q.-M., Vallad, G. E., and Subbarao, K. V. 2008. Characterization of Verticillium dahliae and $V$. tricorpus isolates from lettuce and artichoke. Plant Dis. 92:69-77.

Shah, D., and Madden, L. 2004. Nonparametric analysis of ordinal data in designed factorial experiments. Phytopathology 94:33-43.

Short, D. P. G., Gurung, S., Koike, S. T., Klosterman, S. J., and Subbarao, K. 2015 Frequency of Verticillium species in commercial spinach fields and transmission of $V$. dahliae from spinach to subsequent lettuce crops. Phytopathology 105:80-90.

Short, D. P. G., Gurung, S., Maruthachalam, K., Atallah, Z. K., and Subbarao, K 2014. Verticillium dahliae race 2 -specific PCR reveals a high frequency of race 2 strains in commercial spinach seed lots and delineates race structure. Phytopathology 104:779-785.

Subbarao, K. V., Hubbard, J. C., Greathead, A. S., and Spencer, G. A. 1997 Verticillium wilt. Pages 26-27 in: Compendium of Lettuce Diseases. R. M. Davis, K. V. Subbarao, R. N. Raid, and E. A. Kurtz, eds. American Phytopathological Society, St. Paul, MN.

Taylor, J. 1968. Host range of Verticillium tricorpus (Isaac). N. Z. J. Agric. Res. 11:521-523.

Vallad, G. E., Qin, Q.-M., Grube, R., Hayes, R. J., and Subbarao, K. V. 2006. Characterization of race-specific interactions among isolates of Verticillium dahliae pathogenic on lettuce. Phytopathology 96:1380-1387. 